\title{
ANALISIS PERANCANGAN BAHAN BAKU BERBASIS LISTRIK BERDASARKAN METODE MATERIAL REQUIREMENT PLANNING (MRP) PADA PT. PLN (PERSERO) PUSAT LISTRIK MASOHI
}

\author{
N. E. Maitimu \\ Program Studi Teknik Industri, Fakultas Teknik Universitas Pattimura, Ambon \\ Anton Tonapa \\ PLN Wilayah Maluku dan Maluku Utara, Ambon
}

\begin{abstract}
ABSTRAK
Permintaan akan tenaga listrik yang semakin meningkat membutuhkan persediaan bahan bakar dan material fast moving yang cukup sebagai bahan baku utama dalam penyediaan tenaga listrik. MRP suatu teknik atau prosedur logis untuk menterjemahkan Jadwal Induk Produksi (JIP) dari barang jadi atau end item menjadi kebutuhan bersih untuk beberapa komponen yang dibutuhkan untuk mengimplementasikan JIP. PT PLN (Persero) Pusat Listrik Masohi dalam melakukan permintaan bahan bakar untuk pembangkit listrik dilakukan secara bulanan dan dilakukan pemantauan secara online perhari dimana diperlukan ketepatan pelaporan dan penyediaan bahan bakar untuk penyediaan tenaga listrik yang dinamis. Kebutuhan bahan baku untuk produksi tenaga listrik PT PLN (Persero) Pusat Listrik Masohi telah menggunakan pendekatan metode Economic Order Quantity (EOQ) dalam proses pengadaan material bahan baku. Penelitian ini mendapatkan hasil penggunaaan Metode lot sizing LotFor-Lot, Economic Order Quantity, Part Period Balancing yang optimal untuk digunakan pada Pusat Listrik Masohi adalah Part Period Balancing. Dengan menggunakan metode Part Period Balancing, perusahaan dapat mengurangi biaya persediaan sebesar Rp 1,739,053,883,-, atau sebesar 2,88\% dari total biaya dari metode perusahaan.
\end{abstract}

Kata kunci : Metode MRP, Bill of Materials lot sizing Lot-For-Lot, Economic Order Quantity, Part Period Balancing

\section{ABSTRACT}

An increasing demand of electricity needs sufficient both a fuel and a supply of fast-moving material as raw material in the electricity supply.MRP is a logical procedure to transfer master production schedule from end item to net requirement for few needed components. PT. PLN (Persero) Pusat Listrik Masohi create demand of fuel monthly and control online demand daily where it needed precise of both report and fuel supply in order to provide dynamic electricity. Needs of raw material to produce electricity of PT PLN (Persero) Pusat Listrik Masohi has been used Economic Order Quantity Method (EOQ). In this study, it is found that, by employing Lot For Lot, Economic order quantity and Part period balancing, the optimum method is part period balancing with the inventory cost Rp. 1.739 .053 .883 ,- or 2,88\% of the total cost of company.

Keywords : Metode MRP, Bill of Materials lot sizing Lot-For-Lot, Economic Order Quantity, Part Period Balancing

\section{PENDAHULUAN}

Perkembangan industrialisasi, dan pertumbuhan penduduk yang semakin pesat, memperbesar kebutuhan akan tenaga listrik. Permintaan akan tenaga listrik yang semakin meningkat membutuhkan persediaan bahan baku yang cukup sebagai bahan baku utama dalam penyediaan tenaga listrik. Suatu sistem yang dapat digunakan untuk mengatasi masalah yang berkaitan dengan perencanaan bahan baku produksi dalam hal ini bahan baku adalah Material Requirement Planning (MRP). Sistem ini digunakan untuk menghitung kebutuhan bahan baku yang bersifat dependent (berdasar permintaan) terhadap penyelesaian suatu produk akhir. Dengan sistem MRP, dapat diketahui jumlah bahan baku yang diperlukan untuk menghasilkan suatu produk dimasa yang akan datang sehingga perusahaan dapat mengoptimalkan persediaan bahan baku yang diperlukan agar jumlah persediaan tidak terlalu banyak tetapi juga tidak terlalu sedikit. 
PT PLN (Persero) Pusat Listrik Masohi dalam melakukan permintaan bahan baku untuk pembangkit listrik dilakukan secara bulanan dan dilakukan pemantauan secara online perhari dengan aplikasi SIMBBM dimana diperlukan ketepatan pelaporan dan penyediaan bahan bakar untuk penyediaan tenaga listrik yang dinamis.

Dalam memenuhi kebutuhan bahan baku untuk produksi tenaga listrik PT PLN (Persero) Pusat Listrik Masohi telah menggunakan pendekatan metode Economic Order Quantity (EOQ) dimana besarnya biaya yang digunakan untuk memproduksi tenaga listrik sebesar Rp 60,407,459,743,-. Tujuan dari penerapan sistem MRP adalah untuk merencanakan kapasitas produksi tenaga listrik, meminimalisasi investasi pada pembelian material dan bahan bakar, memaksimalkan efisiensi dari pembangkit dan yang terutama adalah berorientasi pada kepuasan pelanggan.

Tujuan dari penelitian ini adalah untuk Menghitung Lot Size pemesanan bahan baku dari proses produksi listrik di PT PLN (Persero) Pusat Listrik Masohi, untuk Menganalisis rencana kebutuhan bahan baku dalam proses produksi tenaga listrik, dan untuk Mengetahui Metode yang optimal digunakan pada proses produksi tenaga listrik di Pusat Listrik Masohi

\section{LANDASAN TEORI}

\section{Manajemen Persediaan}

Menurut Suryadi (2000) "Persediaan (Inventory) adalah suatu bagian dari kekayaan perusahaan manufaktur yang digunakan dalam rangkaian proses produksi untuk diolah menjadi barang setengah jadi dan akhirnya menjadi barang jadi”.

Menurut Indrajit dan Djokopranoto (2003) "Barang persediaan adalah sejumlah material yang disimpan dan dirawat menurut aturan tertentu dalam tempat persediaan agar selalu dalam keadaan siap pakai dan ditatausahakan dalam buku perusahaan".

Pada umumnya persediaan menurut Assauri (2004) terbagi menjadi:

1. Persediaan Bahan Baku (Raw material stocks)

Persediaan bahan baku yaitu persediaan barang-barang berwujud yang digunakan dalam proses produksi, yang diperoleh dari sumber-sumber alam ataupun dibeli dari supplier atau perusahaan yang menghasilkan bahan baku bagi perusahaan yang menggunakannya.

2. Persediaan Bagian Produk atau Parts yang Dibeli (Purchased parts/Component stock)

Persediaan bagian produksi atau parts yang dibeli dari perusahaan lain, yang dapat secara langsung dirakit dengan part lain, tanpa melalui proses produksi sebelumnya.

3. Persediaan Bahan-bahan Pembantu (Supplies stock)

Persediaan bahan-bahan pembantu yaitu persediaan bahan-bahan yang diperlukan dalam proses produksi untuk membantu berhasilnya produksi atau yang dipergunakan dalam bekerjanya suatu perusahaan, tetapi tidak merupakan bagian atau komponen dari barang jadi.

4. Persediaan Barang Setengah Jadi atau Barang dalam Proses (Work in process/ Progress stock)

Persediaan barang setengah jadi atau barang dalam proses yaitu persediaan barang-barang yang keluar dari tiap-tiap bagian dalam satu pabrik atau bahan-bahan yang telah di olah menjadi suatu bentuk, tetapi diproses kembali untuk kemudian menjadi barangjadi.

5. Persediaan Barang Jadi (Finished goods stock)

Persediaan barang jadi yaitu persediaan barang-barang yang telah selesai di proses atau di olah dalam pabrik dan siap untuk dijual pada pelanggan atau perusahaan lain.
Fungsi persediaan
menurut Tampubolon
(2004)
adalah sebagai berikut:

1. Fungsi Decoupling

Merupakan fungsi perusahaan untuk mengadakan persediaan decouple. Dengan mengadakan pengelompokan operasional secara terpisah-pisah.

2. Fungsi Economic Size

Penyimpanan persediaan dalam jumlah besar dengan pertimbangan adanya diskon atas pembelian bahan, diskon atas kualitas untuk dipergunakan dalam proses konversi, serta didukung kapasitas gudang yang memadai.

3. Fungsi Antisipasi

Merupakan penyimpanan persediaan bahan yang fungsinya untuk penyelamatan jika sampai terjadi keterlambatan datangnya pesanan bahan dari pemasok atau leveransir. Tujuan utama adalah untuk menjaga proses konversi agar tetap berjalan dengan lancar.

Tujuan mengadakan persediaan menurut Indrajit dan Djokopranoto (2003) antara lain: 
1. Memenuhi kebutuhan normal.

2. Memenuhi kebutuhan mendadak

3. Memungkinkan pembelian atas dasar jumlah ekonomis.

Jumlah persediaan yang paling optimal yaitu yang paling ekonomis, dalam arti tidak terlalu banyak, yang berarti pemborosan atau tambahan biaya yang tidak perlu juga tidak terlalu sedikit yaitu masih ada bahaya kehabisan persediaan. Menurut Tampubolon (2004) biayabiaya yang timbul dari adanya persediaan yang digolongkan menjadi empat golongan, yaitu

1. Biaya Pemesanan (Ordering Cost)

Biaya pemesanan adalah biaya-biaya yang dikeluarkan berkenaan dengan pemesanan barang-barang atau bahan-bahan dari penjual sejak dari pemesanan (order) dibuat dan dikirim ke penjual sampai barang- barang atau bahan-bahan tersebut dikirim dan diserahkan serta di inspeksi di gudang. Biaya pemesanan ini sifatnya konstan. Besamya biaya yang dikeluarkan tidak tergantung pada besamya atau banyaknya barang yang dipesan. Dalam ordering cost, yang termasuk kepada biaya pemesanan ini adalah semua biaya yang dikeluarkan dalam rangka mengadakan pemesanan bahan tersebut, di antaranya biaya administrasi pembelian dan penempatan order, biaya pengangkutan dan bongkar muat, biaya penerimaan dan biaya pemeriksaan.

2. Biaya Penyimpanan (Carrying Costs)

Inventory carrying costs adalah biaya-biaya yang diperlukan berkenaan dengan adanya persediaan yang meliputi seluruh pengeluaran yang dikeluarkan perusahaan sebagai akibat dari adanya sejumlah persediaan. Biaya ini berhubungan dengan terjadinya persediaan dan disebut juga dengan biaya mengadakan persediaan (stock holding costs). Biaya ini berhubungan dengan tingkat rata-rata persediaan yang selalu terdapat di gudang, sehingga besamya biaya ini bervariasi tergantung dari besar kecilnya rata-rata persediaan yang terdapat di gudang, yang termasuk kedalam biaya ini adalah semua biaya yang timbul karena barang disimpan yaitu biaya pergudangan yang terdiri dari biaya sewa gedung, upah dan gaji tenaga pengawasa dan pelaksana pergudangan serta biaya lainnya. Biaya pergudangan ini tidak akan ada apabila tidak ada persediaan.

3. Biaya Kehabisan Persediaan (Stockout Cost)

Biaya kehabisan persediaan adalah biaya-biaya yang timbul akibat terjadinya persediaan yang lebih kecil daripada jumlah yang diperlukan, seperti kerugian atau biaya-biaya tambahan yang diperlukan karena seorang pelanggan meminta atau memesan suatu barang sedangkan barang atau bahan yang diperlukan tidak tersedia. Biaya ini juga dapat merupakan biaya- biaya yang timbul akibat pengiriman kembali pesanan atau order tersebut.

4. Biaya Penyiapan (Set Up Cost)

Set up cost adalah biaya-biaya yang timbul didalam menyiapkan mesin dan peralatan untuk dipergunakan dalam proses konversi. Biaya ini terdiri dari biaya mesin yang menganggur (idle capacity), biaya penyiapan tenaga kerja, biaya penjadwalan, biaya kerja lembur, biaya latihan, biaya pemberhentian kerja, dan biaya-biaya pengangguran (idle time costs). Biayabiaya ini terjadi karena adanya pengurangan atau penambahan kapasitas yang digunakan pada suatu waktu tertentu.

\section{Material Requirement Planning (MRP)}

Material Requirement Planning (MRP) adalah metode penjadwalan untuk purchased planned orders dan manufactured planned orders, kemudian diajukan untuk analisis lanjutan berkenaan dengan persediaan kapasitas dan keseimbangan menggunakan perencanaan kebutuhan kapasitas. Sistem MRP mengkoordinasikan pemasaran, manufacturing, pembelian, rekayasa melalui pengadopsian rencana produksi serta melalui penggunaan satu data base terintegrasi guna merencanakan, dan memperbaharui aktivitas dalam sistem industri modern secara keseluruhan, Gasperz (2004).

MRP sangat bermanfaat bagi perencanaan kebutuhan material untuk komponen yang jumlah kebutuhannya dipengaruhi oleh komponen lain (dependent demand). MRP memberikan peningkatan efisiensi karena jumlah persediaan, waktu produksi, dan waktu pengiriman barang dapat direncanakan dengan lebih baik, karena ada keterpaduan dalam kegiatan yang didasarkan pada jadwal induk. Moto dari MRP adalah memperoleh material yang tepat, dari sumber yang tepat, untuk penempatan yang tepat, dan pada waktu yang tepat 
MRP suatu teknik atau prosedur logis untuk menterjemahkan Jadwal Induk Produksi (JIP) dari barang jadi atau end item menjadi kebutuhan bersih untuk beberapa komponen yang dibutuhkan untuk mengimplementasikan JIP. MRP mempunyai tiga fungsi utama yaitu :

1. Mengontrol tingkat inventory

2. Penugasan komponen berdasarkan urutan prioritas

3. Penentuan capacity requirement (kebutuhan kapasitas) pada tingkat yang lebih detil dari setiap proses perencanaan pada rough-cut capacity requirement.

Secara umum, tujuan dari MRP adalah:

1. Meminimalkan persediaan.

2. Mengurangi resiko keterlambatan produksi atau pengiriman

3. Komitmen yang realistis

4. Meningkatkan Efisiensi.

Sistem MRP memiliki empat langkah utama yang harus diterapkan satu per satu pada periode perencanaan dan pada setiap item. Langkah-langkah dasar dalam penyusunan proses MRP adalah sebagai berikut (Nasution, 2003):

1. Netting (kebutuhan bersih) merupakan proses perhitungan untuk menetapkan jumah kebutuhan bersih untuk setiap periode selama horison perencanaan yang besarnya merupakan selisih antara kebutuhan kotor dengan keadaan persediaan (yang ada dalam persediaan dan yang sedang dipesan).

2. Lotting merupakan penentuan ukuran lot (jumlah pesanan) yang menjamin bahwa semua kebutuhan-kebutuhan akan dipenuhi, pesanan akan dijadwalkan untuk penyelesaian pada awal periode dimana ada kebutuhan bersih yang positif.

3. Offsetting (rencana pemesanan) merupakan salah satu langkah pada MRP untuk menentukan saat yang tepat untuk rencana pemesanan dalam memenuhi kebutuhan bersih. Rencana pemesanan didapat dengan cara menggabungkan saat awal tersedianya ukuran lot (lot size) yang diinginkan dengan besarnya waktu ancang- ancang. Waktu ancang-ancang ini sama dengan besarnya waktu saat barang mulai dipesan atau diproduksi sampai barang tersebut siap untuk dipakai.

4. Exploding merupakan proses perhitungan kebutuhan kotor untuk tingkat (level) yang lebih bawah dalam suatu struktur produk serta didasarkan atas rencana pemesanan.

\section{Teknik Pengukuran Ukuran Lot}

1. Lot-For-Lot (L-4-L)

Teknik penetapan ukuran lot dengan ini dilakukan atas dasar pesanan diskrit, disamping itu teknik ini merupakan cara paling sederhana dari semua teknik ukuran lot yang ada yang bertujuan untuk meminimumkan ongkos simpan, sehingga dengan teknik ini ongkos simpan menjadi nol (Nasution \& Prasetyawan, 2008).

2. Economic Order Quantity (EOQ)

Tujuan dari model EOQ adalah untuk meminimalkan total biaya persediaan. Biaya penting adalah biaya pemesanan, biaya penempatan order, dan biaya membawa atau memegang unit persediaan dalam persediaan. Semua biaya lain seperti, misalnya, biaya pembelian persediaan itu sendiri, yang konstan dan karena itu tidak relevan dengan model. Biaya pemesanan juga dikenal sebagai biaya pembelian atau biaya set up, ini adalah jumlah biaya tetap yang terjadi setiap kali item diperintahkan. Biaya tersebut tidak berhubungan dengan kuantitas yang dipesan tapi terutama dengan aktivitas fisik yang dibutuhkan untuk memproses pesanan. Biaya tercatat disebut juga biaya penyimpanan, biaya tercatat adalah biaya yang terkait dengan persediaan yang memiliki di tangan. Hal ini terutama terdiri dari biaya yang berkaitan dengan investasi persediaan dan biaya penyimpanan. Untuk tujuan perhitungan EOQ, jika biaya tidak berubah berdasarkan jumlah persediaan di tangan tidak harus dimasukkan dalam biaya tercatat. Dalam rumus EOQ, biaya membawa direpresentasikan sebagai rata-rata biaya tahunan per unit persediaan.

$$
\text { Rumus EOQ }=\sqrt{\frac{2 S D}{H}}
$$

Keterangan :

D : Penggunaan atau permintaan yang diperkirakan per periode waktu.

$\mathrm{S}$ : Biaya pemesanan ( persiapan pesanan dan penyiapan mesin ) per pesanan.

$\mathrm{H}$ : Biaya penyimpanan per unit per tahun.

3. Part Period Balancing (PPB)

Part Period Balancing (PPB) adalah sebuah pendekatan yang lebih dinamis untuk menyeimbangkan biaya pemesanan dan penyimpanan. PPB menggunakan informasi tambahan dengan mengubah ukuran lot untuk menggambarkan kebutuhan ukuran lot berikutnya di masa datang. (Heizer dan Render, 2008). 
Ukuran lot dicari dengan menggunakan pendekatan sebagian periode ekonomis (economic part period, EPP), yaitu dengan membagi biaya pemesanan dengan biaya penyimpanan per unit per periode. $\mathrm{EPP}=$ biaya pemesanan $I$ biaya penyimpanan per unit per periode

\section{Teori Peramalan}

Peramalan (forecasting) adalah proses untuk memperkirakan jumlah kebutuhan dimasa yang akan datang, yaitu kebutuhan yang meliputi kebutuhan dalam ukuran kuantitas, kualitas, waktu dan lokasi yang dibutuhkan dalam rangka memenuhi permintaan barang ataupun jasa.

Pengukuran kesalahan peramalan dapat dihitung dengan rumus sebagai berikut:

1. MAD (Mean Absolute Deviation) adalah mengukur akurasi peramalan dengan merata-ratakan

kesalahan peramalan (nilai absolutnya)

$$
\text { MAD }=\frac{\sum_{t}\left|e_{t}\right|}{n}
$$

Keterangan:

$\mathrm{e}(\mathrm{t})$ : kesalahan deviasi ) untuk periode yaitu $\mathrm{f}(\mathrm{t})-\mathrm{A}(\mathrm{t})$

$\mathrm{n}$ : nomor periode dimana $\mathrm{e}(\mathrm{t})$ dapat dicari, $\mathrm{i}, \mathrm{e}$, mempunyai kedua $\mathrm{f}(\mathrm{t})$ dan $\mathrm{A}(\mathrm{t})$

2. MSE (Mean Squared Error) adalah merupakan metode alternatif dalam mengevaluasi suatu teknik peramalan. Setiap kesalahan atau residual dikuadratkan, kemudian dijumlahkan dan dibagi dengan jumlah observasi. Persamaannya adalah:

$$
M S E=\frac{\sum_{t}\left(e_{t}\right)^{2}}{n}
$$

Keterangan:

$\mathrm{e}(\mathrm{t})$ : kesalahan deviasi ) untuk periode yaitu $\mathrm{f}(\mathrm{t})-\mathrm{A}(\mathrm{t})$

$\mathrm{n} \quad$ : nomor periode dimana $\mathrm{e}(\mathrm{t})$ dapat dicari, $\mathrm{i}, \mathrm{e}$, mempunyai kedua $\mathrm{f}(\mathrm{t})$ dan $\mathrm{A}(\mathrm{t})$

3. The Mean Absolute Percentage Error (MAPE) dapat dihitung dengan menggunakan kesalahan absolut pada tiap periode dibagi dengan nilai observasi yang nyata untuk periode itu. Kemudian, merata-rata kesalahan persentase absolut tersebut. Pendekatan ini berguna ketika ukuran atau besar variabel ramalan itu penting dalam mengevaluasi ketepatan ramalan. MAPE mengindikasi seberapa besar kesalahan dalam meramal yang dibandingkan dengan nilai nyata pada deret. MAPE dapat dihitung dengan rumus sebagai berikut:

$$
M A P E=\frac{\sum_{t=1}^{N}\left|P E_{t}\right|}{N}
$$

\section{Program POM-QM}

Program POM-QM dari perangkat lunak windows yang merupakan gabungan dari POM for Windows dan QM for Windows. Perangkat lunak ini merupakan produk yang fleksibel dan paling banyak digunakan dibidang manajemen operasi. Program POM-QM merupakan sebuah program bantu komputer yang memiliki beberapa metode untuk memecahkan permasalahan-permasalahan yang berkaitan dengan manajemen operasi dan riset operasi. Dalam penelitian ini, program POM-QM digunakan dalam proses lotting yaitu menentukan ukuran pemesanan.

\section{METODE PENELITIAN}

Metode yang digunakan dalam menyelesaikan masalah dalam penelitian ini adalah dengan menggunakan metode Material Requirement Planning (MRP).

Berikut ini merupakan flowchart dari penelitian ini. 


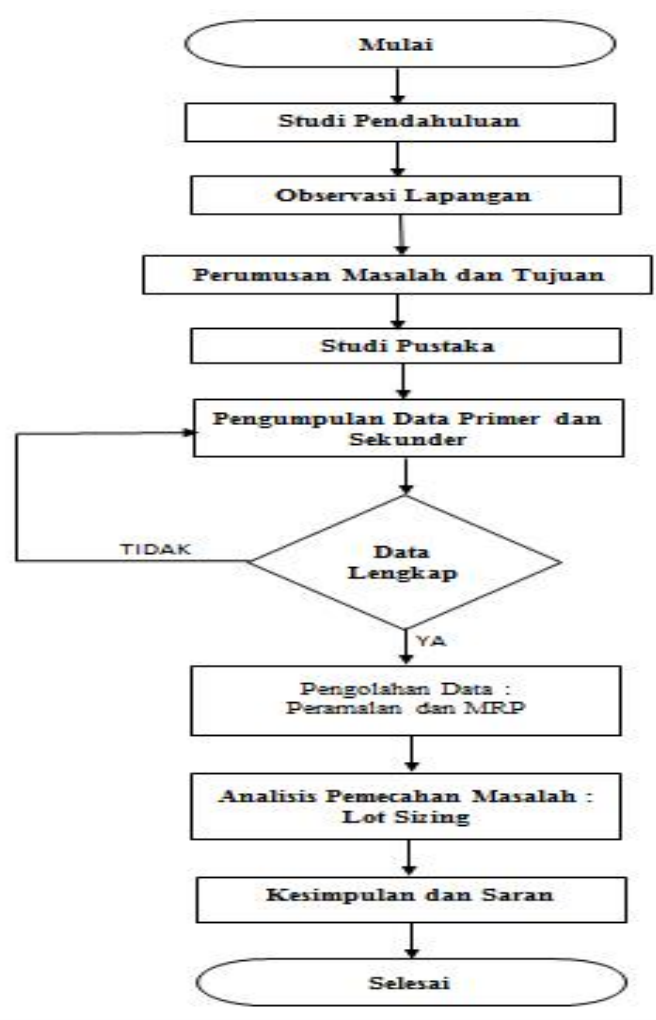

Flowchart Penelitian

\section{HASIL DAN PEMBAHASAN}

Data awal untuk proses perhitungan dapat dilihat pada table dan gambar dibawah:

\section{Penentuan Struktur Produk Tenaga Listrik}

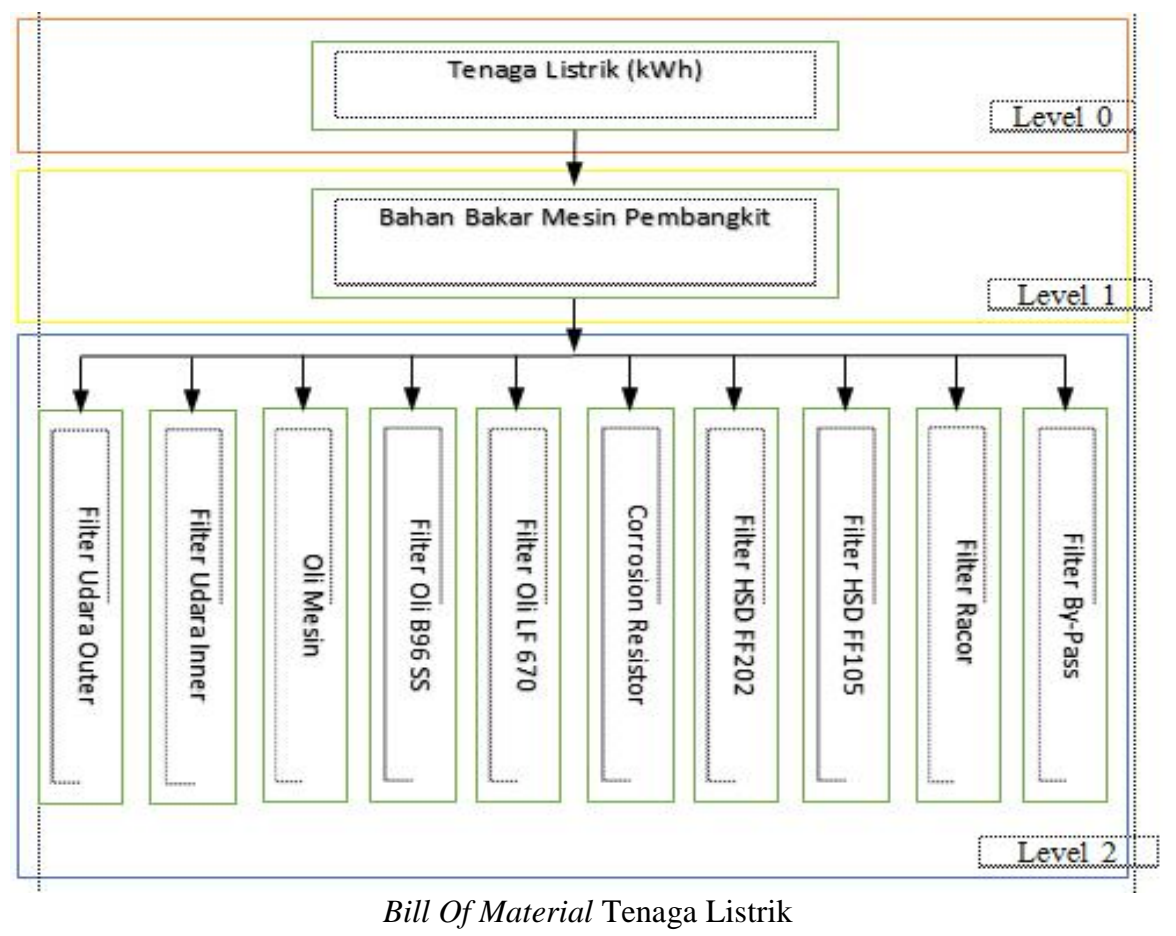




\section{Data Produksi kWh Tenaga Listrik}

Data kWh Produksi Pusat Listrik Masohi Tahun 2016

\begin{tabular}{|c|c|}
\hline Bulan & Tenaga Listrik $(\mathrm{kWh})$ \\
\hline Januari & $3,377,624$ \\
\hline Pebruari & $3,229,534$ \\
\hline Maret & $3,378,335$ \\
\hline April & $3,080,870$ \\
\hline Mei & $3,245,711$ \\
\hline Juni & $3,064,437$ \\
\hline Juli & $2,976,839$ \\
\hline Agustus & $3,064,543$ \\
\hline September & $3,056,087$ \\
\hline Oktober & $3,204,021$ \\
\hline November & $3,320,253$ \\
\hline Desember & $3,378,840$ \\
\hline
\end{tabular}

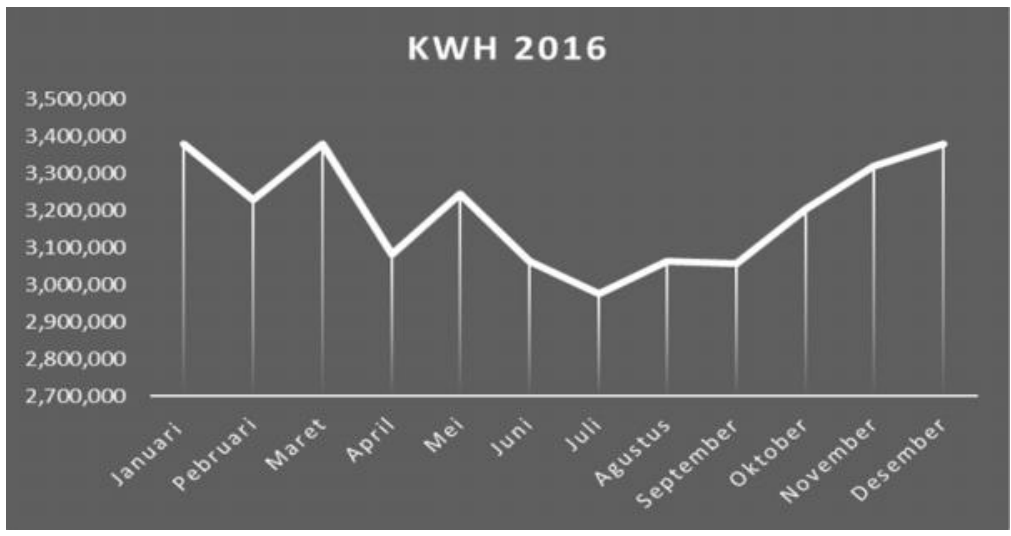

Grafik kWh Produksi Pusat Listrik Masohi Tahun 2016

\section{Daftar Harga Bahan Baku}

Daftar Harga Bahan Baku Utama Tenaga Listrik

\begin{tabular}{|c|l|c|}
\hline No & \multicolumn{1}{|c|}{ Nama } & Harga (Rupiah) \\
\hline 1 & Bahan Bakar (HSD) & 5,810 \\
\hline 2 & Engine Oil & 30,952 \\
\hline 3 & Filter HSD FF105 & 293,370 \\
\hline 4 & Filter HSD FF202 & 320,540 \\
\hline 5 & Filter Oil LF670 & 185,130 \\
\hline 6 & Filter Oil B96 SS & 185,130 \\
\hline 7 & Corrosion Resistor & 635,580 \\
\hline 8 & Filter Racor & 220,320 \\
\hline \hline 9 & Filter By- Pass & 268,180 \\
\hline \hline 10 & Filter Udara Outer & 886,820 \\
\hline \hline 11 & Filter Udara Inner & 351,890 \\
\hline & & \\
\hline
\end{tabular}




\section{Data Inventori Perusahaan}

Data Inventori Perusahaan Bahan Baku Utama Tahun 2016

\begin{tabular}{|c|c|c|c|c|c|c|c|c|c|c|}
\hline No & Nama & $\begin{array}{c}\text { Harga } \\
\text { (Rupiah) }\end{array}$ & Jan & $\mathrm{Feb}$ & Mar & Apr & May & Jun & Jul & Aug \\
\hline 1 & $\begin{array}{l}\text { Bahan } \\
\text { Bakar } \\
\text { (HSD) }\end{array}$ & 5,810 & 750,000 & 750,000 & $1,000,000$ & 850,000 & 850,000 & 850,000 & 850,000 & 850,000 \\
\hline 2 & $\begin{array}{l}\text { Engine } \\
\text { Oil }\end{array}$ & 30,952 & 6270 & 3270 & & 3270 & & 3744 & & 3270 \\
\hline 3 & $\begin{array}{l}\text { Filter } \\
\text { HSD } \\
\text { FF105 }\end{array}$ & 293,370 & 80 & & & & & & & \\
\hline 4 & $\begin{array}{l}\text { Filter } \\
\text { HSD } \\
\text { FF202 }\end{array}$ & 320,540 & 60 & & & 60 & & 60 & & \\
\hline 5 & $\begin{array}{l}\text { Filter Oil } \\
\text { LF670 }\end{array}$ & 185,130 & & & & 24 & & 48 & & 24 \\
\hline 6 & $\begin{array}{l}\text { Filter Oil } \\
\text { B96 SS }\end{array}$ & 185,130 & 48 & 30 & 24 & 60 & 30 & 48 & 40 & 30 \\
\hline 7 & $\begin{array}{l}\text { Corrosion } \\
\text { Resistor }\end{array}$ & 635,580 & & & 20 & & & 20 & & \\
\hline 8 & $\begin{array}{l}\text { Filter } \\
\text { Racor }\end{array}$ & 220,320 & 10 & 34 & & 34 & & & 42 & \\
\hline 9 & $\begin{array}{l}\text { Filter By- } \\
\text { Pass }\end{array}$ & 268,180 & 48 & 6 & & 6 & & 32 & & 40 \\
\hline 10 & $\begin{array}{l}\text { Filter } \\
\text { Udara } \\
\text { Outer }\end{array}$ & 886,820 & & 14 & & 14 & & & & \\
\hline 11 & $\begin{array}{l}\text { Filter } \\
\text { Udara } \\
\text { Inner }\end{array}$ & 351,890 & & 14 & & 14 & & & & \\
\hline
\end{tabular}

\section{Biaya Pesan (Ordering Cost)}

Biaya Pemesanan Bahan Baku Utama Tahun 2016

\begin{tabular}{|c|c|c|}
\hline No & Nama Bahan & Biaya Pemesanan (Rp) \\
\hline 1 & Bahan Bakar (HSD) & 55.89 \\
\hline 2 & Engine Oil & $4,700.00$ \\
\hline 3 & Filter HSD FF105 & $169,500.00$ \\
\hline 4 & Filter HSD FF202 & $169,500.00$ \\
\hline 5 & Filter Oil LF670 & $180,800.00$ \\
\hline 6 & Filter Oil B96 SS & $192,100.00$ \\
\hline 7 & Corrosion Resistor & $113,000.00$ \\
\hline 8 & Filter Racor & $135,600.00$ \\
\hline 9 & Filter By- Pass & $169,500.00$ \\
\hline 10 & Filter Udara Outer & $678,000.00$ \\
\hline 11 & Filter Udara Inner & $226,000.00$ \\
\hline
\end{tabular}




\section{Biaya Penyimpanan}

Biaya penyimpanan adalah semua pengeluaran atau biaya yang timbul akibat menyimpan barang maupun bahan. Biaya penyimpanan yang diperhitungkan berupa biaya karena memiliki persediaan (biaya modal) dan biaya kerusakan atau penyusutan. Biaya karena memiliki persediaan (biaya modal) dapat diukur dengan suku bunga bank sebesar $4.5 \%$ per tahun (berdasarkan suku bunga BI 22 Agustus 2017) dari harga material per unit. Untuk biaya penyusutan atau kerusakan dapat dihitung berdasarkan penyusutan atau kerusakan material selama penyimpanan yang sebesar 0,5\% dari meter faktor Standar penelitian PT PLN (persero) Pusat Pengembangan dan Penelitian Ketenagalistrikan. Dengan asumsi bahwa 1 tahun ada 365 hari, maka perhitungan biaya penyimpanan material per hari adalah sebagai berikut :

Biaya Penyimpanan $=\frac{(4.5 \%+0.5 \%)}{365} \times$ Harga Material per unit

$$
=\frac{5 \%}{365} x \text { Harga Material per unit }
$$

Biaya Penyimpanan Bahan Baku Utama

\begin{tabular}{|c|c|c|c|c|}
\hline No & Nama Bahan & $\begin{array}{c}\text { Harga } \\
\text { Material }\end{array}$ & $\%$ & $\begin{array}{c}\text { Biaya Simpan/Hari } \\
(\mathrm{Rp})\end{array}$ \\
\hline $\mathrm{a}$ & $\mathrm{b}$ & $\mathrm{c}$ & $\mathrm{d}$ & $\mathrm{e}=(\mathrm{d} / 365) * \mathrm{c}$ \\
\hline 1 & $\begin{array}{c}\text { Bahan Bakar } \\
\text { (HSD) }\end{array}$ & 5810 & 5 & 0.80 \\
\hline 2 & Engine Oil & 30951 & 5 & 4.24 \\
\hline 3 & Filter HSD FF105 & 293370 & 5 & 40.19 \\
\hline 4 & Filter HSD FF202 & 320540 & 5 & 43.91 \\
\hline 5 & Filter Oil LF670 & 185130 & 5 & 25.36 \\
\hline 6 & Filter Oil B96 SS & 185130 & 5 & 25.36 \\
\hline 7 & Corrosion Resistor & 635580 & 5 & 87.07 \\
\hline 8 & Filter Racor & 220320 & 5 & 30.18 \\
\hline 9 & Filter By- Pass & 268180 & 5 & 36.74 \\
\hline 10 & Filter Udara Outer & 886820 & 5 & 121.48 \\
\hline 11 & Filter Udara Inner & 351890 & 5 & 48.20 \\
\hline
\end{tabular}

\section{Peramalan}

Berdasarkan plot data yang ada maka dilakukan permalan dengan moving average dan single exponential smoothing. Berikut ini adalah hasilnya

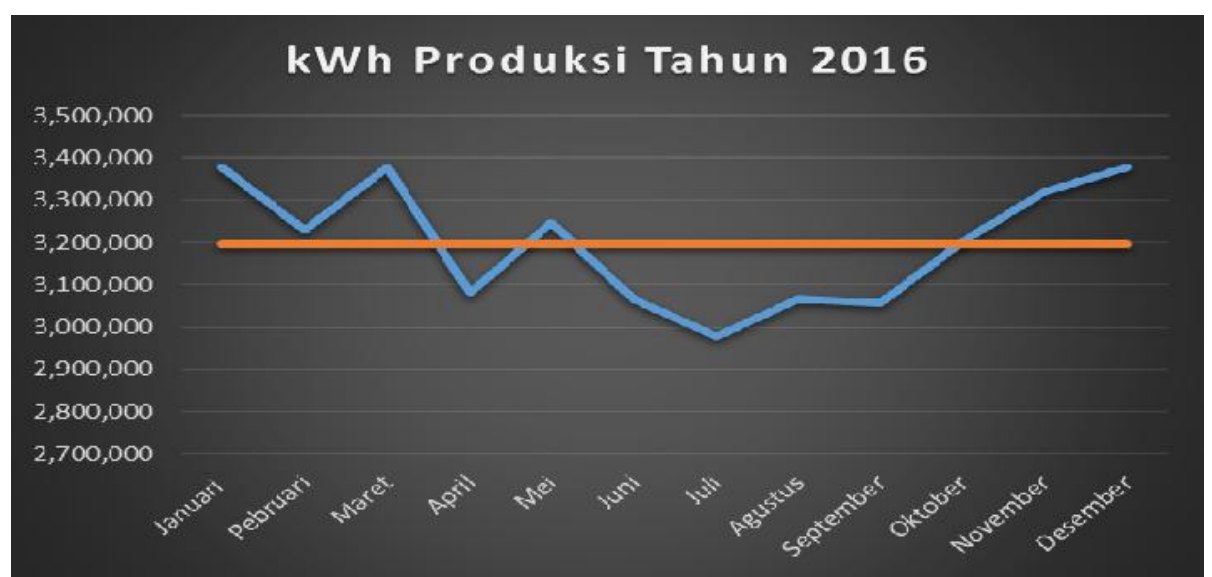

Rata-Rata kWh Produksi PT. PLN (Persero) Pusat Listrik Masohi Tahun 2016 
Perbandingan Standar Error Untuk Metode Exponential Smoothing, Least Squares Dan Moving Average

\begin{tabular}{|c|c|c|c|c|c|}
\hline \multirow{2}{*}{$\begin{array}{c}\text { Forecasting } \\
\text { Results } \\
\end{array}$} & \multicolumn{3}{|c|}{ Exponential Smoothing } & \multirow{2}{*}{$\begin{array}{c}\text { Least } \\
\text { squares }\end{array}$} & \multirow{2}{*}{$\begin{array}{l}\text { Moving } \\
\text { Average }\end{array}$} \\
\hline & $\alpha=0.60$ & $\alpha=0.70$ & $\alpha=0.80$ & & \\
\hline $\begin{array}{l}\text { Bias (Mean } \\
\text { Error) }\end{array}$ & -6992.92 & -3674 & -1702.25 & -0.08 & 12062.05 \\
\hline $\begin{array}{c}\text { MAD } \\
\text { (Mean } \\
\text { Absolute } \\
\text { Deviation) }\end{array}$ & 112574.9 & 113717.5 & 115034 & 124613.3 & 112092.6 \\
\hline $\begin{array}{c}\text { MSE (Mean } \\
\text { Squared } \\
\text { Error) }\end{array}$ & 18322050000 & 17939420000 & 18167700000 & 19513500000 & 17077260000 \\
\hline $\begin{array}{c}\text { Standart } \\
\text { Error } \\
(\text { Denom }=\text { n- } \\
2=9) / \\
(\text { denom }=\text { n- } \\
2-4=6)\end{array}$ & 148278.3 & 146721.9 & 147652.4 & 153023.5 & 146104.7 \\
\hline $\begin{array}{c}\text { MAPE } \\
\text { (Mean } \\
\text { Absolute } \\
\text { Percent) }\end{array}$ & 0.04 & 0.04 & 0.04 & 0.04 & 0.04 \\
\hline
\end{tabular}

Peramalan Moving Average menggunakan program POM-QM For Windows Version 36

\begin{tabular}{|l|r|r|r|r|r|r|}
\hline & Demand(y) & Forecast & \multicolumn{1}{|c|}{ Error } & \multicolumn{1}{|l|}{ Error } & \multicolumn{1}{|l|}{ Error^2 } & \multicolumn{1}{|l|}{ Ect } \\
\hline January & 3377624 & & & & & \\
\hline February & 3229534 & & & & & \\
\hline March & 3378335 & 3303579 & 74756 & 74756 & 5588460000 & 0.02 \\
\hline April & 3080870 & 3303935 & 223064.5 & 223065 & 49757770000 & 0.07 \\
\hline May & 3245711 & 3229603 & 16108.5 & 16108.5 & 259483800 & 0 \\
\hline June & 3064437 & 3163291 & -98853.5 & 98853.5 & 9772015000 & 0.03 \\
\hline July & 2976839 & 3155074 & -178235 & 178235 & 31767720000 & 0.06 \\
\hline August & 3064543 & 3020638 & 43905 & 43905 & 1927649000 & 0.01 \\
\hline September & 3056087 & 3020691 & 35396 & 35396 & 1252877000 & 0.01 \\
\hline October & 3204021 & 3060315 & 143706 & 143706 & 20651410000 & 0.04 \\
\hline November & 3320253 & 3130054 & 190199 & 190199 & 36175660000 & 0.06 \\
\hline December & 3378840 & 3262137 & 116703 & 116703 & 13619590000 & 0.03 \\
\hline TOTALS & 38377100 & & 120620.5 & 1120927 & $1.70773 E+11$ & 0.35 \\
\hline $\begin{array}{l}\text { AVERAGE } \\
\text { Next } \\
\text { period } \\
\text { forecast }\end{array}$ & 3198091 & & 12062.05 & 112093 & 17077260000 & 0.04 \\
\hline & & & & & & \\
\hline
\end{tabular}

Dari hasil ramalan yang terpilih dipakai untuk membuat jadwal induk produksi yang terlihat pada table dibawah ini. 
Jadwal Induk Produksi Tahun 2017 Berdasarkan Hasil Pengolahan Data

\begin{tabular}{|c|c|c|}
\hline BULAN & $\begin{array}{c}\text { Peramalan } \\
\text { permintaan }(\mathbf{k W h})\end{array}$ & $\begin{array}{c}\text { Jadwal Induk } \\
\text { Produksi }(\mathbf{k W h})\end{array}$ \\
\hline JANUARI & $3,377,624$ & $3,377,624$ \\
\hline FABRUARI & $3,229,534$ & $3,229,534$ \\
\hline MARET & $3,303,579$ & $3,303,579$ \\
\hline APRIL & $3,303,935$ & $3,303,935$ \\
\hline MEI & $3,229,603$ & $3,229,603$ \\
\hline JUNI & $3,163,291$ & $3,163,291$ \\
\hline JULI & $3,155,074$ & $3,155,074$ \\
\hline AGUSTUS & $3,020,638$ & $3,020,638$ \\
\hline SEPETEMBER & $3,020,691$ & $3,020,691$ \\
\hline OKTOBER & $3,060,315$ & $3,060,315$ \\
\hline NOPEMBER & $3,130,054$ & $3,130,054$ \\
\hline DESEMBER & $3,262,137$ & $3,262,137$ \\
\hline TOTAL & $38,256,475$ & $38,256,475$ \\
\hline
\end{tabular}

Perhitungan Jumlah Kebutuhan Bahan Baku

Data Perhitungan Jumlah Kebutuhan Bahan Baku

\begin{tabular}{|c|l|c|c|c|}
\hline No & \multicolumn{1}{|c|}{ Nama } & Satuan & $\begin{array}{c}\text { Penggunaan } \\
\text { Bahan Baku } \\
\text { per kWh }\end{array}$ & $\begin{array}{c}\text { Total kebutuhan Bahan } \\
\text { Baku Desember 2017 }\end{array}$ \\
\hline 1 & Bahan Bakar (HSD) & Liter & 0.258 & 871740.72 \\
\hline 2 & Engine Oil & Liter & 0.00061 & 2061.09 \\
\hline 3 & Filter HSD FF105 & Buah & $2.08 \mathrm{E}-06$ & 7.04 \\
\hline 4 & Filter HSD FF202 & Buah & $5.73 \mathrm{E}-06$ & 19.37 \\
\hline 5 & Filter Oil LF670 & Buah & $3.91 \mathrm{E}-06$ & 43.85 \\
\hline 6 & Filter Oil B96 SS & Buah & $1.30 \mathrm{E}-05$ & 7.04 \\
\hline 7 & Corrosion Resistor & Buah & $2.08 \mathrm{E}-06$ & 11.45 \\
\hline 8 & Filter Racor & Buah & $3.39 \mathrm{E}-06$ & 4.40 \\
\hline 9 & Filter By- Pass & Buah & $5.89 \mathrm{E}-06$ & 4.40 \\
\hline 10 & Filter Udara Outer & Buah & $1.30 \mathrm{E}-06$ & \\
\hline 11 & Filter Udara Inner & & $1.30 \mathrm{E}-06$ & \\
\hline
\end{tabular}




\section{Proses Menggunakan MRP Dengan Perhitungan Lot Sizing}

1. Perhitungan Metode Lot For Lot

Hasil Output Program Pom-Qm V3 Metode Lot FOR Lot Bahan Bakar

\begin{tabular}{|c|c|c|c|c|c|c|c|}
\hline No & Period & Demand & $\begin{array}{l}\text { Order } \\
\text { receipt }\end{array}$ & Inven & $\begin{array}{l}\text { Hold } \\
\text { ing } \\
\text { Cost }\end{array}$ & Setup Cost & $\begin{array}{l}\text { Total Cost } \\
\text { (Rp) }\end{array}$ \\
\hline 1 & $\begin{array}{l}\text { Initial } \\
\text { Inventory }\end{array}$ & & & 0 & & & \\
\hline 2 & January & 871427 & 871427 & 0 & & 46115260 & 5.109 .106 .130 \\
\hline 3 & February & 833220 & 833220 & 0 & & 46115260 & 4.887 .123 .460 \\
\hline 4 & March & 871611 & 871611 & 0 & & 46115260 & $5,110.175 .170$ \\
\hline 5 & April & 794864 & 794864 & 0 & & 46115260 & $4.664,275.100$ \\
\hline 6 & May & 837393 & 837393 & 0 & & 46115260 & 4.911 .368 .590 \\
\hline 7 & June & 790625 & 790625 & 0 & & 46115260 & $4.639,646.510$ \\
\hline 8 & July & 768024 & 768024 & 0 & & 46115260 & $4,508,334,700$ \\
\hline 9 & August & 790652 & 790652 & 0 & & 46115260 & $4,639,803,380$ \\
\hline 10 & September & 788470 & 788470 & 0 & & 46115260 & 4.627 .125 .960 \\
\hline 11 & October & 826637 & 826637 & 0 & & 46115260 & $4,848,876,230$ \\
\hline 12 & November & 856625 & 856625 & 0 & & 46115260 & $5,023.106 .510$ \\
\hline 13 & December & 871741 & 871741 & 0 & & 46115260 & $5,110,930,470$ \\
\hline 14 & Totals & & & & & & $\begin{array}{c}58,079,872,21 \\
0\end{array}$ \\
\hline
\end{tabular}

Pesanan bahan bakar kebutuhan bersih setiap bulan dengan menggunakan metode lot for lot, perusahaan hanya mengeluarkan biaya pemesanan yang dihitung sebagai berikut :

Biaya Pemesanan Total : $\quad 58.079 .872 .210,-$

Biaya Penyimpanan Total : $\quad \frac{0,-}{58.079 .872 .210,-}$

Biaya Total Persediaan : $\quad 58.079 .872 .210,-$

Dengan menggunakan metode Lot For Lot biaya total persediaan bahan bakar tahun 2016 sebesar Rp 58.079.872.210,- sedangkan dengan menggunakan metode perusahaan sebesar Rp 59.262.000.000,-, sehingga terdapat selisih sebesar Rp 1.186.623.782,--

Total Output Program POM-QM V3 Biaya Persediaan Metode Lot for Lot

\begin{tabular}{|c|c|c|c|c|c|c|c|}
\hline \multirow{2}{*}{ No } & & \multicolumn{7}{|c|}{ Total cost per bulan (Rp) } \\
\cline { 2 - 8 } & Item & Jan & Feb & Mar & Apr & May & Jun \\
\hline 1 & Bahan Bakar (HSD) & $5,109,105,870$ & $4,887,123,200$ & $5,110,174,910$ & $4,664,274,840$ & $4,911,368,330$ & $4,639,646,250$ \\
\hline 2 & Engine Oil & $63,779,061$ & $60,983,257$ & $63,792,370$ & $58,176,311$ & $61,288,434$ & $57,866,182$ \\
\hline 3 & Filter HSD FF105 & $2,069,389$ & $1,975,510$ & $2,066,455$ & $1,884,565$ & $1,987,245$ & $1,875,764$ \\
\hline 4 & Filter HSD FF202 & $6,208,761$ & $5,936,302$ & $6,211,967$ & $5,663,843$ & $5,968,356$ & $5,634,995$ \\
\hline 5 & Filter Oil LF670 & $2,445,976$ & $2,338,601$ & $2,445,976$ & $2,231,225$ & $2,351,560$ & $2,220,117$ \\
\hline 6 & Filter Oil B96 SS & $8,122,220$ & $7,766,770$ & $8,124,071$ & $7,409,469$ & $7,805,648$ & $7,370,592$ \\
\hline 7 & Corrosion Resistor & $4,481,592$ & $4,278,206$ & $4,475,236$ & $4,081,177$ & $4,303,630$ & $4,062,109$ \\
\hline 8 & Filter Racor & $2,521,930$ & $2,411,770$ & $2,521,930$ & $2,301,610$ & $2,422,786$ & $2,288,391$ \\
\hline 9 & Filter By-Pas5 & $5,337,292$ & $5,103,976$ & $5,337,292$ & $4,867,977$ & $5,128,112$ & $4,843,841$ \\
\hline 10 & Filter Udara Outer & $3,904,833$ & $3,736,337$ & $3,904,833$ & $3,558,973$ & $3,754,074$ & $3,550,105$ \\
\hline 11 & Filter Udara Inner & $1,549,257$ & $1,482,398$ & $1,549,257$ & $1,412,020$ & $1,489,436$ & $1,408,501$ \\
\hline
\end{tabular}

\begin{tabular}{|c|c|c|c|c|c|c|}
\hline & & & & & & Total (Rp) \\
\hline Jul & Aug & Sep & Oct & Nov & Dec & \\
\hline $4,508,334,440$ & $4,639,803,120$ & $4,627,125,700$ & $4,848,875,970$ & $5,023,106,250$ & $5,110,930,210$ & $58,079,869,090$ \\
\hline $56,212,160$ & $57,868,039$ & $57,708,332$ & $60,501,350$ & $62,695,776$ & $63,801,965$ & $724,673,236$ \\
\hline $1,822,958$ & $1,875,764$ & $1,869,897$ & $1,960,842$ & $2,031,250$ & $2,066,455$ & $23,486,094$ \\
\hline $5,471,519$ & $5,634,995$ & $5,618,968$ & $5,891,427$ & $6,102,983$ & $6,211,967$ & $70,556,084$ \\
\hline $2,157,173$ & $2,220,117$ & $2,212,712$ & $2,320,088$ & $2,405,247$ & $2,447,827$ & $27,796,620$ \\
\hline $7,159,544$ & $7,370,592$ & $7,350,228$ & $7,705,677$ & $7,985,224$ & $8,125,923$ & $92,295,958$ \\
\hline $3,947,705$ & $4,062,109$ & $4,049,398$ & $4,246,427$ & $4,398,967$ & $4,475,236$ & $50,861,792$ \\
\hline $2,222,295$ & $2,288,391$ & $2,281,781$ & $2,391,941$ & $2,480,069$ & $2,524,133$ & $28,657,025$ \\
\hline $4,704,387$ & $4,843,841$ & $4,830,432$ & $5,063,749$ & $5,246,111$ & $5,339,974$ & $60,646,984$ \\
\hline $3,443,687$ & $3,550,105$ & $3,532,369$ & $3,700,864$ & $3,842,756$ & $3,904,833$ & $44,383,768$ \\
\hline $1,366,274$ & $1,408,501$ & $1,401,463$ & $1,468,322$ & $1,524,625$ & $1,549,257$ & $17,609,311$ \\
\hline \multicolumn{6}{|c|}{ Totol Cost } & $59,220,835,961$ \\
\hline
\end{tabular}


2. Perhitungan Metode Economic Order Quantity

\begin{tabular}{|c|c|c|r|r|r|r|}
\hline No & $\begin{array}{c}\text { Frekuensi } \\
\text { Pesanan } \\
\text { (Kali) }\end{array}$ & $\begin{array}{c}\text { Jumlah } \\
\text { Pesanan } \\
\text { (Liter) }\end{array}$ & $\begin{array}{c}\text { Persediaan rata- } \\
\text { rata } \\
\text { (Liter) }\end{array}$ & $\begin{array}{c}\text { Biaya Pesanan } \\
\text { (Rupiah) }\end{array}$ & $\begin{array}{c}\text { Biaya } \\
\text { Penyimpanan } \\
\text { (Rupiah) }\end{array}$ & $\begin{array}{c}\text { Biaya Total } \\
\text { (Rupiah) }\end{array}$ \\
\hline 1 & 1 & 9.901 .290 & 825.108 & 553.383 .109 & $7.880 .341,93$ & 561.263 .451 \\
\hline 2 & 40 & 247532 & 20.628 & 13.834 .578 & $197.008,55$ & 14.031 .586 \\
\hline 3 & 80 & 123766 & 10.314 & 6.917 .289 & $98.504,27$ & 7.015 .793 \\
\hline 4 & 120 & 82511 & 6.876 & 4.611 .526 & $65.669,52$ & 4.677 .195 \\
\hline 5 & 160 & 61883 & 5.157 & 3.458 .644 & $49.252,14$ & 3.507 .897 \\
\hline 6 & 200 & 49506 & 4.126 & 2.766 .916 & $39.401,71$ & 2.806 .317 \\
\hline 7 & 240 & 41255 & 3.438 & 2.305 .763 & $32.834,76$ & 2.338 .598 \\
\hline
\end{tabular}

Rumus EOQ $=\mathrm{Q}=\sqrt{\frac{2 \mathrm{SD}}{\mathrm{H}}}=\sqrt{\frac{2 \times 55,89 \times 9,901,290}{4,624}}=1,539,427$ liter/pesanan

Jumlah frekuensi pesanan yang paling ekonomis ialah :

$\mathrm{F}=\frac{\mathrm{D}}{\mathrm{Q}}=\frac{9,901290}{1,539,427}=6$ kali per tahun

3. Perhitungan Menggunakan Program POM-QM V3

4.

Hasil Output Program POM-QM V3 Perhitungan Metode Economic Order Quantity Bahan Bakar

\begin{tabular}{|c|c|c|c|c|c|c|c|}
\hline No & Period & Demand & $\begin{array}{c}\text { Order } \\
\text { receipt }\end{array}$ & Inven & $\begin{array}{c}\text { Holding } \\
\text { Cost }\end{array}$ & $\begin{array}{c}\text { Setup } \\
\text { Cost }\end{array}$ & $\begin{array}{c}\text { Total Cost } \\
\text { (Rp) }\end{array}$ \\
\hline 1 & Initial Inventory & & 0 & & & \\
\hline 2 & January & 871427 & 925268 & 53841 & 43073 & 46115 & $5,375,896,849$ \\
\hline 3 & February & 833220 & 925268 & 145889 & 116711 & 46115 & $5,375,970,487$ \\
\hline 4 & March & 871611 & 925268 & 199546 & 159637 & 46115 & $5,376,013,413$ \\
\hline 5 & April & 794864 & 616845 & 21528 & 17222 & 46115 & $3,583,935,111$ \\
\hline 6 & May & 837393 & 925268 & 109403 & 87522 & 46115 & $5,375,941,298$ \\
\hline 7 & June & 790625 & 925268 & 244046 & 195237 & 46115 & $5,376,049,013$ \\
\hline 8 & July & 768024 & 616845 & 92868 & 74294 & 46115 & $3,583,992,183$ \\
\hline 9 & August & 790652 & 925268 & 227484 & 181987 & 46115 & $5,376,035,763$ \\
\hline 10 & September & 788470 & 616845 & 55859 & 44687 & 46115 & $3,583,962,576$ \\
\hline 11 & October & 826637 & 925268 & 154490 & 123592 & 46115 & $5,375,977,368$ \\
\hline 12 & November & 856625 & 925268 & 223133 & 178507 & 46115 & $5,376,032,283$ \\
\hline 13 & December & 871741 & 925268 & 276660 & 221328 & 46115 & $5,376,075,104$ \\
\hline 14 & Totals & 9901289 & 10177950 & 1804748 & 1443798 & 553380 & $59,135,881,449$ \\
\hline
\end{tabular}


Total Hasil Output Program POM-QMV3 Biaya Persediaan Metode Economic Order Quantity

\begin{tabular}{|c|c|c|c|c|c|c|c|}
\hline \multirow{2}{*}{ No } & & \multicolumn{6}{|c|}{ Total cost per bulan (Rp) } \\
\hline & Item & Jan & Feb & Mar & Apr & May & Jun \\
\hline 1 & Bahan Balkar (HSD) & $5,375,896,849$ & $5,375,970,487$ & $5,376,013,413$ & $3,583,935,111$ & $5,375,941,298$ & $5,376,049,013$ \\
\hline 2 & Engine Oil & $89,863,497$ & $89,867,457$ & $89,871,031$ & 3,134 & $89,866,973$ & $89,871,360$ \\
\hline 3 & Filter HSD FF 105 & $5,575,640$ & 210 & $5,575,851$ & 433 & 161 & $5,575,827$ \\
\hline 4 & Filter HSD FF 202 & $16,352,036$ & 577 & $16,352,613$ & 1,190 & 373 & $16,352,488$ \\
\hline 5 & Filter Oil LF670 & $8,704,227$ & 537 & 202 & $8,704,459$ & 767 & 463 \\
\hline 6 & Filter Oil B96 SS & $30,002,029$ & 1,934 & 822 & $30,002,949$ & 2,849 & 1,840 \\
\hline 7 & Corrosion Resistor & $6,992,477$ & $6,992,849$ & 103 & $6,992,635$ & $6,993,003$ & 314 \\
\hline 8 & Filter Racor & $7,052,330$ & 290 & $7,052,620$ & 596 & 264 & $7,052,626$ \\
\hline 9 & Filter By- Pass & $15,290,815$ & 665 & $15,291,480$ & 1,362 & 659 & $15,291,543$ \\
\hline 10 & Filter Udara Outer & $12,419,471$ & 654 & 120 & $12,419,638$ & 820 & 335 \\
\hline 11 & Filter Udara Inner & $4,575,925$ & 211 & $4,576,137$ & 433 & 229 & 36 \\
\hline
\end{tabular}

\begin{tabular}{|c|c|c|c|c|c|c|c|}
\hline \multirow{2}{*}{ No } & \multicolumn{6}{|c|}{ Total cost per bulan (Rp) } & \multirow{2}{*}{ Total (RP) } \\
\hline & Jul & Aug & Sep & Oct & Nov & Dec & \\
\hline 1 & $3,583,992,183$ & $5,376,035,763$ & $3,583,962,576$ & $5,375,977,368$ & $5,376,032,283$ & $5,376,075,104$ & $59,135,8 B 1,449$ \\
\hline 2 & 3,732 & $89,868,040$ & 207 & $89,864,154$ & $89,867,879$ & $89,871,452$ & $808,818,917$ \\
\hline 3 & 418 & 161 & $5,575,829$ & 400 & 122 & $5,575,763$ & $27,8 B 0,814$ \\
\hline 4 & 1,092 & 320 & $16,352,437$ & 984 & 148 & $16,352,184$ & $81,766,440$ \\
\hline 5 & 168 & $8,704,426$ & 753 & 436 & 107 & $8,704,334$ & $34,820,581$ \\
\hline 6 & 860 & $30,002,992$ & 2,954 & 1,900 & 807 & $30,002,836$ & $120,024,772$ \\
\hline 7 & $6,992,864$ & 175 & $6,992,711$ & $6,993,087$ & 351 & $6,992,829$ & $55,943,398$ \\
\hline 8 & 612 & 299 & $7,052,662$ & 625 & 286 & $7,052,615$ & $35,265,824$ \\
\hline 9 & 1,447 & 783 & 122 & $15,290,975$ & 805 & 73 & $61,170,729$ \\
\hline 10 & $12,419,869$ & 1,079 & 596 & 89 & $12,419,569$ & 730 & $49,6 \mathrm{B2}, 970$ \\
\hline 11 & $4,575,987$ & 284 & 92 & $4,576,029$ & 309 & 97 & $18,305,768$ \\
\hline & \multicolumn{6}{|c|}{ Total Cost } & $60,429,561,962$ \\
\hline
\end{tabular}

5. Perhitungan Menggunakan Metode Part Period Balancing (PPB)

Hasil Output Program POM-QM V3 Perhitungan Metode Part Period Balancing Bahan Bakar

\begin{tabular}{|c|c|c|c|c|c|c|c|}
\hline No & Period & Demand & $\begin{array}{c}\text { Order } \\
\text { receipt }\end{array}$ & Inven & $\begin{array}{c}\text { Holding } \\
\text { Cost }\end{array}$ & $\begin{array}{c}\text { Setup } \\
\text { Cost }\end{array}$ & Total Cost (Rp) \\
\hline 1 & Initial Invt & & & 0 & & & \\
\hline 2 & January & 871427 & 871427 & 0 & & 46115 & $5,063,036,985.00$ \\
\hline 3 & February & 833220 & 833220 & 0 & & 46115 & $4,841,054,315.00$ \\
\hline 4 & March & 871611 & 871611 & 0 & & 46115 & $5,064,106,025.00$ \\
\hline 5 & April & 794864 & 794864 & 0 & & 46115 & $4,618,205,955.00$ \\
\hline 6 & May & 837393 & 837393 & 0 & & 46115 & $4,865,299,445.00$ \\
\hline 7 & June & 790625 & 790625 & 0 & & 46115 & $4,593,577,365.00$ \\
\hline 8 & July & 768024 & 768024 & 0 & & 46115 & $4,462,265,555.00$ \\
\hline 9 & August & 790652 & 790652 & 0 & & 46115 & $4,593,734,235.00$ \\
\hline 10 & September & 788470 & 788470 & 0 & & 46115 & $4,581,056,815.00$ \\
\hline 11 & October & 826637 & 826637 & 0 & & 46115 & $4,802,807,085.00$ \\
\hline 12 & November & 856625 & 856625 & 0 & & 46115 & $4,977,037,365.00$ \\
\hline 13 & December & 871741 & 871741 & 0 & & 46115 & $5,064,861,325.00$ \\
\hline 14 & Totals & 9901289 & 9901289 & 0 & 0 & 553380 & $57,527,042,470$ \\
\hline
\end{tabular}


Total Output Program POM-QM V3 Biaya Metode Part Period Balancing Material

\begin{tabular}{|c|c|c|c|c|c|c|c|c|c|c|}
\hline \multirow[b]{2}{*}{$\mathrm{Ne}$} & \multirow{2}{*}{\multicolumn{2}{|c|}{ Item }} & \multicolumn{8}{|c|}{ Total cost per bulan (Rp) } \\
\hline & & & \multicolumn{2}{|c|}{\begin{tabular}{|l|l} 
Jan \\
\end{tabular}} & \multicolumn{2}{|l|}{ Feb } & Mar & Apr & May & Jun \\
\hline 1 & \multicolumn{2}{|c|}{ Bahan Balsar (HSD) } & \multicolumn{2}{|c|}{$5,063,036,985$} & \multicolumn{2}{|c|}{$4,841,054,315$} & $5,064,106,025$ & $4,618,205,955$ & $4,865,299,445$ & $4,593,577,365$ \\
\hline 2 & \multicolumn{2}{|c|}{ Engine Oil } & \multicolumn{2}{|c|}{$124,765,223$} & \multicolumn{2}{|c|}{-} & $121,971,118$ & - & $119,156,927$ & - \\
\hline 3 & \multicolumn{2}{|c|}{ Filter HSD FF 105} & \multicolumn{2}{|c|}{$6,109,647$} & \multicolumn{2}{|l|}{283} & - & $5,745,844$ & 257 & - \\
\hline 4 & \multicolumn{2}{|c|}{ Filter HSD FF 202} & \multicolumn{2}{|c|}{$18,352,480$} & \multicolumn{2}{|l|}{851} & - & $17,262,569$ & 772 & - \\
\hline 5 & Filter Oil LF & & 9,455 & & 640 & & 305 & - & $8,943,091$ & 599 \\
\hline 6 & Filter Oil B9 & & 31,40 & .804 & 2,126 & & 1,014 & - & $29,685,457$ & 1,988 \\
\hline 7 & Corrosion Re & & 8,759 & & - & & $8,556,219$ & - & $8,365,542$ & - \\
\hline 8 & Filter Racor & & 7,453 & & 345 & - & - & $9,231,623$ & 618 & 304 \\
\hline 9 & Filter $\mathrm{By}-\mathrm{Ps}$ & & 15,29 & 8,815 & 665 & & $15,291,480$ & 1,362 & 659 & $15,291,543$ \\
\hline 10 & Filter Udara & & 15,09 &, 034 & 1,022 & & 487 & - & $14,273,200$ & 956 \\
\hline 11 & Filter Udara & & 5,990 & & 405 & & 193 & - & $5,663,423$ & 379 \\
\hline & & & Total & & & & & & & \\
\hline & & & & Total cost & tper & bulan (Rp) & & & Total (F & \\
\hline$\frac{J_{v}}{4 .}$ & $2,265.555$ & $\frac{\text { Aug }}{4.593,734,2}$ & & $\frac{\operatorname{sep}}{4,581,056,81}$ & & $\begin{array}{l}\text { Oct } \\
4.802,807.085\end{array}$ & $\begin{array}{l}\text { Nov } \\
4.977,037,36\end{array}$ & $\begin{array}{l}\text { Dec } \\
5,064,861,325\end{array}$ & $\frac{10 t a r(k}{57.527 .0}$ & \\
\hline & $.082,359$ & - & & $118,212,325$ & & - & 126.501 .084 & - & 724,689 & \\
\hline & 6.872 & 256 & & - & & $6,056,848$ & 283 & - & 23.4802 & \\
\hline & 20,809 & 769 & & - & & $18.201,849$ & 851 & - & 70.540 .9 & \\
\hline 30 & & - & & 9.380 .076 & & 664 & 335 & - & $27,781,9$ & \\
\hline & & - & & $31,146,395$ & & 2,205 & 1.112 & - & $92,243.1$ & \\
\hline & 9.617 & - & & 8.295 .654 & & - & $8,874,063$ & - & $50,860.7$ & \\
\hline- & & 6.959 .814 & & 327 & & - & $5,003.079$ & - & $28,649.4$ & \\
\hline & & 783 & & 122 & & $15,290,975$ & 805 & 73 & $61,170$. & \\
\hline 48 & & - & & $14.973,914$ & & 1.061 & 535 & - & $44,349$. & \\
\hline 19 & & - & & $5.941,466$ & & 421 & 212 & - & $17,597,4$ & \\
\hline & & & & & arat & $\cos t$ & & & 58. & 05.860 \\
\hline
\end{tabular}

\section{KESIMPULAN}

Berdasarkan penelitian dan hasil pembahasan yang dilakukan, maka penulis menarik kesimpulan sebagai berikut:

1. Menggunakan metode MRP dengan perhitungan lot sizing pada Pusat Listrik Masohi dapat dapat membantu perencanaan kebutuhan bahan baku setiap item produk secara tepat waktu, sehingga proses produksi akan terlaksana dengan baik sesuai kapasitas yang direncanakan dan order dapat terpenuhi tepat waktu.

2. Kebutuhan bahan baku proses produksi tenaga listrik di Pusat Listrik Masohi dalam mengendalikan persediaan bahan baku yaitu dengan metode Lot-For-Lot sebesar Rp 59,220,835,961 , Economic Order Quantity Rp 60,429,561,962, Part Period Balancing Rp 58,668,405,860 dan Metode perusahaan Rp 60,407,459,743.

3. Hasil penggunaaan Metode lot sizing Lot-For-Lot, Economic Order Quantity, Part Period Balancing yang optimal untuk digunakan pada Pusat Listrik Masohi adalah Part Period Balancing. Dengan menggunakan metode Part Period Balancing, perusahaan dapat mengurangi biaya persediaan sebesarRp $1,739,053,883,-$, atau sebesar $2,88 \%$ dari total biaya dari metode perusahaan.

\section{DAFTAR PUSTAKA}

Arman Hakim Nasution, (2003)., Perencanaan dan Pengendalian Produksi, Edisi I, Guna Widya, Surabaya.

Assauri, Sofjan, (2004)., Manajemen Produksi dan Operasi, Edisi Revisi. Lembaga Penerbit Fakultas Ekonomi Universitas Indonesia, Jakarta.

Gasperz, V., (2004)., Production Planning and Inventory Control berdasarkan pendekatan sistem terintergrasi MRP II dan JIT menuju manufaktur 21, Gramedia Pustaka Utama, Jakarta.

Indrajit, E., Richardus, Djokopranoto, R., (2002)., Concept Management Supply Chain. Gramedia, Jakarta.

Indrajit, E., Richardus, Djokopranoto, R., (2003)., Manajemen Persediaan.Jakarta: Grasindo. Jakarta

Manufacturing MRP and Forecasting (Online) http://www.greentree.com/Product_sheets/manufacturing_mrp_and_forecasting.pdf

Nasution, F., Natigor.,(2004)., Just in Time dan Perkembangannya dalam Perusahaan Industri. Universitas Sumatera Utara, Fakultas Ekonomi: Sumatera Utara 2004.

Tampubolon,(2004)., Manajemen Operasional. PT. Ghalia Indonesia: Jakarta 
